swept over the face of the mountain, driving the rain in almost horizontal sheets along the surface. From time to time mists floated over the mountain, and it was bitterly cold.

Iceland a Meteorological Station.--If Iceland were connected with the Faëroe Islands, and with the north of Scotland by telegraph, there can be no doubt that it would form a valuable meteorological station, although from the various disturbing influences the effect of which would be comparatively local, such as the jokulls and the various local currents, such a station would be less valuable than would be afforded by a vessel moored 600 or 800 miles out in the Atlantic between Ireland and Newfoundland, and in telegraphic communication with the central office in London.

Drift Wood of Iceland.--Great quantities of drift wood are thrown upon the southern coast of Iceland. It is said to be chiefly fir, and it is asserted by some to come from Siberia by an arctic current, and by others from America by the Gulf Stream. We noticed that the coast between Grindavik Staðr and Cape Reykjanes was far more thickly strewn with drift wood than the coast more to the east in the neighbourhood of Eyrarbakki. As the Gulf Stream impinges on the south-western peninsula, it would seem that it must therefore be the chief source of the drift wood. The trees that we saw were torn up by the roots, and they were completely blanched, and in many cases riddled with holes by some species of borer. A portion of the skeleton of a large whale was visible on the shore near Grindavik.

Improvements in Iceland.-During the year which has elapsed since we last visited Iceland, several very marked improvements have been set on foot. In no respect is this more conspiculous than in the case of the roads. A few years ago a writer made the assertion "there are no roads in Iceland." At the present time road-making is making great progress, and many scores of miles of excellent roads exist. Of course we mean such roads as alone are possible, without great expenditure of money and labour, in a country which is one vast volcano. Driving roads are impossible, but excellent pony roads are being constructed, and will greatly facilitate despatch of business and intercommunication. The first bridge in Iceland is about to be commenced. It will cross the Olfusà, and materially help to establish a better communication between the east and the west. A second bridge is to be thrown across the Thjorsa. The first lighthouse in the island was erected a year ago, and the lightdues paid by ships at the port of Reykjavik have already almost paid for its construction. There is some talk of founding a school of farming at Moorudalr in the northwest, and a law school in Reykjavik, where a divinity school and a medical school already exist. In Reykjavik new houses are being built; there is a proposition on foot to build an hotel, and a new house for the Althing, which now holds its biennial meetings in the Latin school. Hafnafjord and Eyrarbakki are flourishing little ports Akureyri does a fair trade in shark liver oil, and in ponies and the Krisuvik sulphur mines appear to be in good working order, and to yield a rich product.

Reykjavik, September 2

G. F. RODWELI

\section{ON HARMONIC RATIOS IN THE SPECTRA OF GASES}

PROF. G. JOHNSTONE STONEY has given in the April number of the Phil. $\mathrm{Mag}$. for I 87 I some remarkable ratios of the wave-lengths of three of the hydrogen lines. Prof. Soret and Mr. Lecoq de Boisbaudran have also given several similar ratios, and I have found at various times a great many. It is, however, impossible to decide, without a thorough discussion, how many of these harmonic ratios may be due to accident. All possible fractions in a given spectrum ought to be calculated, and we could then see, by the theory of probability, whether the coincidences with ratios of comparatively small numbers are more numerous than we ought to expect. I began this work about a year ago. The calculation and discussion of twenty thousand fractions will necessarily take some time. The following simple ratios, however, which I have found in the iron-spectrum, I believe to be worth recording. I may say that I have gone only through the seventh part of that spectrum as yet. The first column in the following table contains the corrected wavelengths of iron lines as given by Angström. If these numbers are multiplied by the fractions given in the second column, we obtain the calculated values of other iron lines. The observed values and difference are given in the fourth and fifth columns.

\begin{tabular}{|c|c|c|c|c|}
\hline$\lambda$ & Fraction. & Calculated. & Observed. & $\Delta$ \\
\hline $6302 \cdot 49$ & $8: 10$ & $504 r \cdot 99$ & $504 r \cdot 69$ & -0.30 \\
\hline $6231 \cdot 64$ & $5: 6$ & 5193.03 & 5193.25 & +0.21 \\
\hline \multirow[t]{2}{*}{$6192: 43$} & 9 : ro & $5573 \cdot 19$ & 5573.37 & +0.18 \\
\hline & $6: 7$ & 5307.80 & 5308.10 & +0.30 \\
\hline \multirow[t]{2}{*}{6 I $37 \cdot 53$} & $8: 9$ & $5455^{\circ} 5^{8}$ & $5456 \cdot 36$ & +0.72 \\
\hline & $7: 8$ & $5370 \cdot 34$ & $5370 \cdot 65$ & +0.31 \\
\hline \multirow{3}{*}{$\begin{array}{l}6066^{*} 39 \\
6009^{\circ} 32\end{array}$} & $7: 8$ & $5308 \cdot 09$ & $5308 \cdot 10$ & $+0^{\circ} \mathrm{OI}$ \\
\hline & $8: 9$ & $534 \mathrm{r}^{-62}$ & $534 \mathrm{I}^{\circ} \cdot 87$ & +0.25 \\
\hline & $2: 3$ & $4006 \cdot 2$ & 4006.0 & -0.2 \\
\hline \multirow[t]{2}{*}{$6003^{\circ} 92$} & $\begin{array}{l}7: 10 \\
5: 6\end{array}$ & $4202 \cdot 74$ & 4202.75 & +0.01 \\
\hline & & $5003^{\circ} 27$ & 5003.52 & +0.25 \\
\hline
\end{tabular}

The differences could of course be reduced to one-half by throwing part of them on the possible errors in the observation of the wave-lengths given in the first column. It is to be remarked that the intensities of the iron lines which figure in the above table are as a rule very strong. Thus all but three of the lines have an intensity of over six attached to them in Watts' Index.

The following table contains a set of iron lines, which can be arranged as harmonics of a fundamental vibration whose wave-length is 0.018694765 of a millimetre.

The table is arranged according to the pattern of that given by Prof. Stoney for the hydrogen lines.

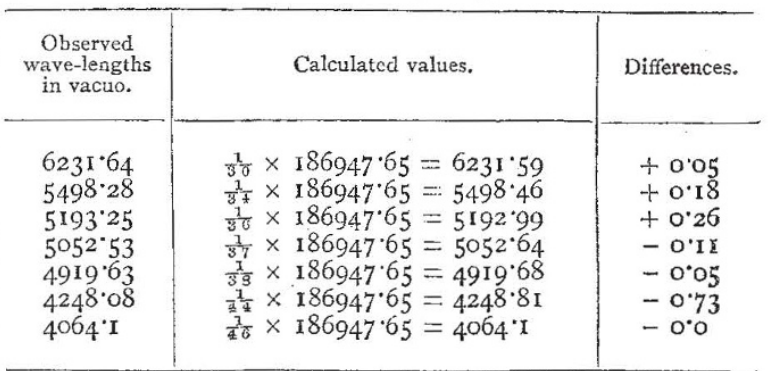

I have included the forty-fourth harmonic, because Thalén gives 4248.8 for the observed value of the wavelength, which reduces the difference to zero. I must, of course, complete the investigation before I can definitely say in how far all these coincidences may be due to accident. On the whole, as far as I have hitherto gone, the result does not seem to be decisive in favour of such a simple connection between the wave lengths of different lines. The true law of the distribution has not yet, I believe, been found, but harmonic ratios may take a secondary part. ARTHUR SCHUSTER

\section{OUR ASTRONOMICAL COLUMN}

PALISA'S COMET. - The following elements of this comet have been calculated by Mr. Hind from the first Pola observation on August 2 I, one at Leipsic on August 28, and M. Henry's observation at Paris on September II:- 